\section{Tissue Printing for Scanning Electron Microscopy and Microanalysis}

Barbara A. Reine, University of Washington

The study of plant morphology and plant cells in the scanning electron microscope is often compromised by the limitations of specimen preparation techniques. Air drying usually results in unacceptable shrinkage and distortion of the normal surface morphology of plant cells. Chemical fixation followed by criitical point drying or chemical drying using fluorocarbon compounds improves morphological results but still imparts artifacts, adds chemical constituents to the specimen, and requires the use of toxic chemicals, a hood, and much time.

One technique that eliminates many of these disadvantages and is even suitable for specimen preparation in the field is tissue printing. For easy, quick recording of stem anatomy and collection of cell exudates for subsequent analysis, its "elegant simlicity ${ }^{\text {(.) }}$ is compelling. Historically, the application of tissue printing has been in connection with optical microscopy ${ }^{1.23}$. However, this technique works very well for SEM and associated elemental characterization of residues by $x$-ray microanalysis. The tissue print technique applied to SEM is much the same as for optical microscopy.

This work reports the use of tissue printing to reveal both anatomical stem structure and chemical analysis of cell exudates in a SEM equipped with an energy dispersive spectrometer. Various species of Equisetum were collected from the environs of Seattle, WA and one tropical species, Equisetum giganteum, was collected from the Caracas Botanical Garden in Venezuela. Stems of these various species were cut transversely and longitudinally and the sections were imprinted on $0.45 \mu \mathrm{m}$ pore size nitrocellulose membranes as shown in Figure 1. A variation on this technique omits the top protective paper and the hand-cut section, substituting an entire stem freshly cut at the desired position. This variation is especially desirable for field work and for increasing the amount of cell sap collected. Either method creates both an anatomical and chemical imprint. These imprinted nitorcellulose membranes are then dried, cut to size, attached to specimen mounts and coated with either carbon or gold-palladium. Imaging and x-ray microanalysis are performed directly on the imprinted membrane.

These anatomical and chemical imprints allow morphological and analytical determination of differences between species and/or growth conditions. Figure 2 shows the anatomical detail present in an imprint of a stem cross-section of Equisetum arvense. This imprint exhibits stem anatomy reflecting the epidermal layer $(E)$, the vallecular canal $(V C)$, the carinal canal (cc) and the central cabity (C), as well as individual cell outlines from the outer epidermis to the central cavity. Cell sap or exudate collected by tissue printing from Equiseturm telmatela and from $E$. giganieum have strikingly different appearances and $\mathrm{x}$-ray microanalysis corroborates this difference. The exudate from $E$. telmateia is virtually pure silica while the exudate from E. giganteum is composed of calcium, potassium, chlorine, magnesium and very little silica. These differences might be a function of age, growing conditions or actual species differences as suggested by previous work on ashed material $^{4}$. Besides being a rapid method for recording anatomical structure of plants, these results indicate the tissue printing technique is helpful in analysing elements taken up by plants from the soil

References

1 Cassab. G.I \& Varner. J.E. (1989) Tissue Printing On Nitrocellulose Paper A New Method for Immunolocatization of Proteins, Localization of Enzyme Activities and Anatomical Aanalysis, Cell Biol Inthl Reports 13: 147-152

2 Reid, PD et al. (1990) Anatomical Changes and Immunolocalization of Cellulase During Abscission as Observed on Nitrocellulose Tissue Prints. Plant Physiol 93, 160 3 Reid, P D \& Pont-Lezica, R.F. (ed.) (1992) Tissue Printing Tools for the Study of Anatomy. Histochemistry, and Gene Expression. Academic Press, San Diego.

4 Reine B.A (1992) Localization of Silica in Equisetum arvense (Horselail). Proc. EMSA 1992, San Francisco Press, 856

Editors Note This novel new technique for scanning electron microscopy was presented in the Plant Cell Structure Symposium at the 1993 MSA Meeting in Cincinnati This text was exceroted from the MSA Proceedings. Page 140-141

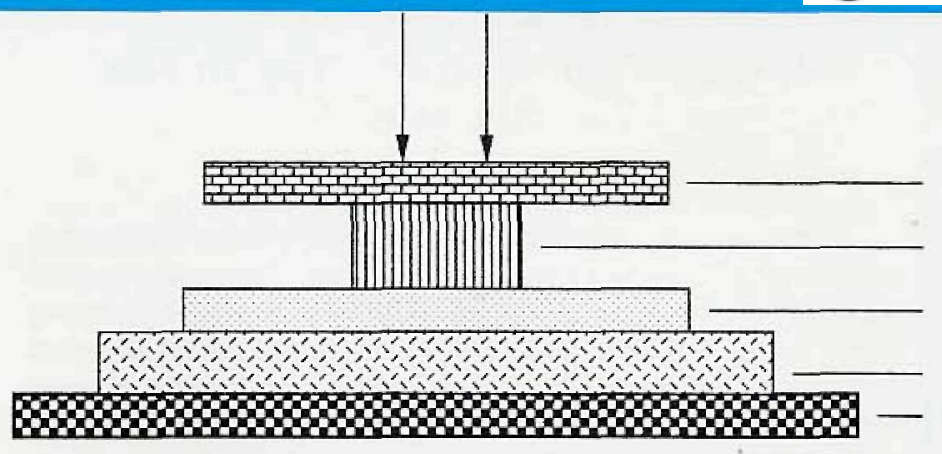

A - Protective paper

$B$ - Tissue section, 200 to $500 \mu m$ thick

C - Dry nitrocellulose membrane, 0.45 um pore size

D - 2 to 4 layers of paper towels

E - Glass Plate

Fig. 1. Diagram of Tissue Print Technique: Firm pressure applied from above

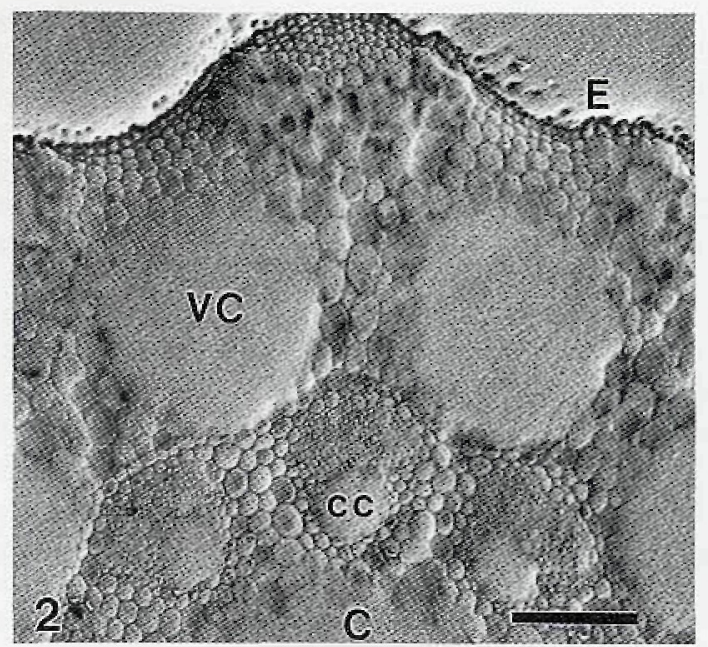

Fig. 2. SEM image of Tissue Print of Equisetun arvense Stem Cross-section, Bar $=145 \mu \mathrm{m}$

\section{SENIOR FACULTY POSITION IN MICROSCOPYI MICROANALYSIS/ MATERIALS SCIENCE AND ENGINEERING}

The Department of Materials Science and Engineering at Lehigh University has an opening for a senior (associate/full) professor with expertise in electron microscopy and/or microanalysis (SEM, TEM, AEM, etc.). The successful candidate must have a proven record of research in the application of microscopy and/or microanalysis to the solution of materials problems and be able to conduct independent and cooperative research in MS\&E. Ability to teach undergraduates and graduate courses in microscopy and materials is essential. Experience in running a microscopy facility will be an advantage. Position available September 1, 1994

Curriculum vitae and the names of three references should be sent by May 15, 1994 to:

Professor David B. Williams

Chairman, Search Committee

Dept. of Materials Science \& Engineering

Lehigh University

5 East Packer Ave

Bethlehem, PA 18015

Lehigh University is an equal opportunity employer and welcomes applications from all qualified candidates.

A
B
C
D
E 